\title{
Asymmetric Au-catalyzed cycloisomerization of 1,6-enynes: An entry to bicyclo[4.1.0]heptene
}

Alexandre Pradal, Chung-Meng Chao, Patrick Y. Toullec

and Véronique Michelet ${ }^{*}$

Open Access

\author{
Full Research Paper

\section{Address:} \\ Laboratoire Charles Friedel, UMR 7223, Ecole Nationale Supérieure \\ de Chimie de Paris, Chimie ParisTech, 11 rue P. et M. Curie, F-75231 \\ Paris Cedex 05, France \\ Email: \\ Véronique Michelet ${ }^{*}$ - veronique-michelet@chimie-paristech.fr \\ * Corresponding author \\ Keywords: \\ asymmetric catalysis; bicycloheptene; cycloisomerization reactions; \\ enynes; gold
}

\author{
Beilstein J. Org. Chem. 2011, 7, 1021-1029. \\ doi:10.3762/bjoc.7.116 \\ Received: 02 May 2011 \\ Accepted: 12 July 2011 \\ Published: 26 July 2011 \\ This article is part of the Thematic Series "Gold catalysis for organic \\ synthesis". \\ Guest Editor: F. D. Toste \\ (C) 2011 Pradal et al; licensee Beilstein-Institut. \\ License and terms: see end of document.
}

\begin{abstract}
A comprehensive study on the asymmetric gold-catalyzed cycloisomerization reaction of heteroatom tethered 1,6-enynes is described. The cycloisomerization reactions were conducted in the presence of the chiral cationic $\mathrm{Au}(\mathrm{I})$ catalyst consisting of $(R)-4-$ MeO-3,5- $(t \text { - } \mathrm{Bu})_{2}$-MeOBIPHEP- $(\mathrm{AuCl})_{2}$ complex and silver salts $\left(\mathrm{AgOTf}\right.$ or AgNTf $\left.\mathrm{A}_{2}\right)$ in toluene under mild conditions to afford functionalized bicyclo[4.1.0]heptene derivatives. The reaction conditions were found to be highly substrate-dependent, the best results being obtained in the case of oxygen-tethered enynes. The formation of bicyclic derivatives, including cyclopropyl pentasubstituted ones, was reported in moderate to good yields and in enantiomeric excesses up to $99 \%$.
\end{abstract}

\section{Introduction}

Metal-catalyzed cycloisomerization reactions of $1, n$-enynes have emerged as efficient processes that contribute to sustainable development and atom economy concepts [1-8]. In the last ten years, they have provided extremely efficient access to cyclic skeletons with a broad range of functional moieties. Among them, the synthesis of oxa- and azabicyclo[4.1.0]heptenes starting from heteroatom-linked 1,6enynes has been recently a field of high interest considering the fundamental skeleton rearrangement research of $1, n$-enynes
[1-11] and the potential applications in biological active and natural products $[12,13]$. In 1995, Blum et al. described a novel $\mathrm{PtCl}_{4}$-catalyzed cycloisomerization reaction of allyl propynyl ethers leading to oxabicyclo[4.1.0]heptenes [14] (Scheme 1, reaction 1). The group of Murai observed a similar reactivity in the presence of $\mathrm{PtCl}_{2}$, although in a lower yield [15]. These seminal contributions were then followed by several comprehensive studies involving carbophilic complexes such as platinum or gold [16-22] that led to the formation of complex 
bicyclic and tricyclic compounds [23-40]. The first asymmetric version was described by Shibata's group in 2005 in the presence of a chiral iridium catalyst [41] (Scheme 1, reaction 2). We and others recently pursued the improvement and development of this enantioselective process, by employing platinum [4244], rhodium [45] or gold [46-48] complexes. Following our previous work with chiral gold catalysts [46], we report a comprehensive study on gold-catalyzed enantioselective synthesis of bicyclo[4.1.0]heptenes, focusing on the scope and limitations of such systems.
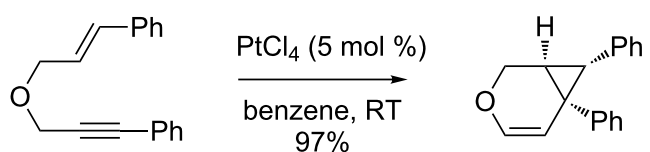
$97 \%$

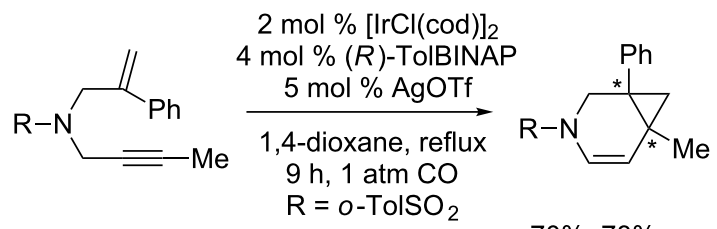

$70 \%, 78 \%$ ee

Scheme 1: First reports on the racemic and asymmetric synthesis of bicyclo[4.1.0]heptenes.

\section{Results and Discussion Optimization of the catalytic system}

Based on our ongoing program on asymmetric gold catalysis [46,49-52], and on literature reports [53-55], we selected 4-MeO-3,5-( $t-\mathrm{Bu})_{2}-\mathrm{MeOBIPHEP}-(\mathrm{AuCl})_{2}$ complex [56-58] as the best candidate for such a transformation. Initial experiments were performed using $N$-tosyl allyl substrate 1a and oxygenlinked propargylic 1,6-enyne $\mathbf{2 a}$ as model substrates (Table 1). The reaction of $\mathbf{1 a}$ was evaluated in various solvents and proceeded smoothly leading to the desired alkene 3a [59]. The reaction kinetics and stereoselectivity were found to be highly solvent-dependent, the enantiomeric excesses (ee) varying from $31 \%$ to $78 \%$ at room temperature (Table 1 , entries $1-3$ ). The reaction kinetic was very slow at room temperature in ether and toluene, but high ee's were obtained. Increasing the temperature to $40^{\circ} \mathrm{C}$ in toluene or ether had a positive effect both on the conversion and on the ee's (Table 1, entries 4 and 5). The reaction was also conducted at $60{ }^{\circ} \mathrm{C}$ or $70{ }^{\circ} \mathrm{C}$ with good conversions and ee's (Table 1, entries 6-8), the best results being obtained in toluene. At $80{ }^{\circ} \mathrm{C}$ in toluene, a decrease in the stereoselectivity was observed as the ee dropped to $91 \%$ (Table 1, entry 9). The reactivity of oxygen-tethered enynes such as $\mathbf{2 a}$ was different to that for $\mathbf{1 a}$ as a complete conversion was observed at room temperature in toluene, dichloromethane, ether and tetrahydrofuran (Table 1, entries 10-13). A better ee

Table 1: Cycloisomerization reaction of nitrogen- and oxygen-linked 1,6-enynes $\mathbf{1 a}$ and $\mathbf{2 a}$.

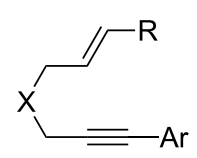

$1 \mathrm{a}, 2 \mathrm{a}$

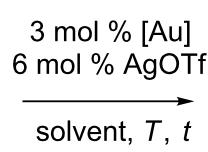

solvent, $T, t$

Substrate

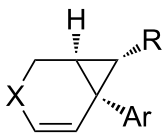

3a, $4 a$
$\mathrm{X}=\mathrm{NTs}, \mathrm{Ar}=\mathrm{Ph}, \mathrm{R}=\mathrm{H} 1 \mathrm{a}$

$\mathrm{X}=\mathrm{O}, \mathrm{Ar}=4-\mathrm{MeOC}_{6} \mathrm{H}_{4}, \mathrm{R}=\mathrm{Ph} \mathbf{2 a}$

$[\mathrm{Au}]=(R)-4-\mathrm{MeO}-3,5-(t-\mathrm{Bu})_{2} \mathrm{MeOBIPHEP}-(\mathrm{AuCl})_{2}$

\begin{tabular}{|c|c|c|c|c|c|c|c|}
\hline Entry & Substrate & Solvent & $T\left[{ }^{\circ} \mathrm{C}\right]$ & $t[\mathrm{~h}]$ & $\begin{array}{l}\text { Conv. (Yield) } \\
{[\%]^{a}}\end{array}$ & Product & ee $[\%]^{b}$ \\
\hline 1 & $1 \mathrm{a}$ & $\mathrm{CH}_{2} \mathrm{Cl}_{2}$ & $\mathrm{RT}$ & 36 & 78 & $3 a$ & $31(-)$ \\
\hline 2 & $1 a$ & $\mathrm{Et}_{2} \mathrm{O}$ & $\mathrm{RT}$ & 39 & 17 & $3 a$ & $75(-)$ \\
\hline 3 & $1 a$ & toluene & $\mathrm{RT}$ & 39 & 11 & $3 a$ & $78(-)$ \\
\hline 4 & $1 \mathrm{a}$ & $\mathrm{Et}_{2} \mathrm{O}$ & 40 & 41 & 28 & $3 a$ & $90(-)$ \\
\hline 5 & $1 a$ & toluene & 40 & 96 & $100(47)$ & $3 a$ & $98(-)$ \\
\hline 6 & $1 a$ & toluene & 60 & 96 & $100(74)$ & $3 a$ & $98(-)$ \\
\hline 7 & $1 a$ & THF & 60 & 96 & 69 & $3 a$ & $74(-)$ \\
\hline 8 & $1 a$ & toluene & 70 & 96 & $100(83)$ & $3 a$ & $96(-)$ \\
\hline 9 & $1 \mathrm{a}$ & toluene & 80 & 48 & 66 & $3 a$ & $91(-)$ \\
\hline 10 & $2 a$ & toluene & RT & 30 & $100(57)$ & $4 a$ & $92(-)$ \\
\hline 11 & $2 a$ & $\mathrm{CH}_{2} \mathrm{Cl}_{2}$ & RT & 25 & $100(26)$ & $4 a$ & $70(-)$ \\
\hline 12 & $2 a$ & $\mathrm{Et}_{2} \mathrm{O}$ & RT & 25 & $100(35)$ & $4 a$ & $91(-)$ \\
\hline 13 & $2 a$ & THF & RT & 25 & $100(43)$ & $4 a$ & $85(-)$ \\
\hline 14 & $2 a$ & toluene & 0 & 120 & $100(56)$ & $4 a$ & $96(-)$ \\
\hline
\end{tabular}

adetermined by ${ }^{1} \mathrm{H}$ NMR, ${ }^{b}$ determined by HPLC. 


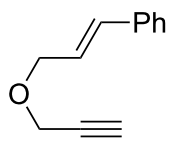

5

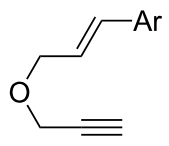

6

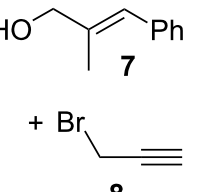

8
$5 \mathrm{~mol} \% \mathrm{PdCl}_{2}\left(\mathrm{PPh}_{3}\right)_{2}$

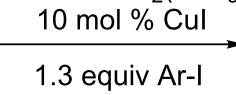

$\mathrm{iPr}_{2} \mathrm{NH}, \mathrm{RT}, 3 \mathrm{~h}$

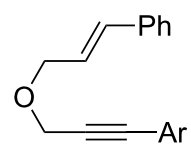

$\mathrm{Ar}=3,5-\mathrm{Me}_{2} \mathrm{C}_{6} \mathrm{H}_{3}, 71 \% \mathbf{2 b}$

$\mathrm{Ar}=4-\mathrm{CO}_{2} \mathrm{MeC}_{6} \mathrm{H}_{4}, 75 \% 2 \mathrm{c}$

$\mathrm{Ar}=4-\mathrm{NO}_{2} \mathrm{C}_{6} \mathrm{H}_{4}, 85 \%$ 2d

$\mathrm{Ar}=3-\mathrm{BrC}_{6} \mathrm{H}_{4}, 73 \% 2 \mathrm{e}$

Scheme 2: Synthesis of oxygen-tethered 1,6-enynes.

was obtained in toluene compared to other solvents. Cyclopropyl alkene 4 a was isolated in $56 \%$ yield and $96 \%$ ee at $0{ }^{\circ} \mathrm{C}$ in toluene (Table 1, entry 14). Toluene was therefore chosen for further studies.

\section{Synthesis of 1,6-enynes}

We prepared various oxygen-tethered 1,6-enynes according to classic methodologies employing a Williamson alkylation reaction and/or a Sonogashira cross-coupling [60,61] (Scheme 2 and Scheme 3). The known enyne 5 [62,63] was engaged in Pd-catalyzed coupling in the presence of diversely functionalized aryl iodides (Scheme 2). The corresponding substituted alkynes $\mathbf{2 b - e}$ [46] were isolated in $71-85 \%$ yield. An analogous 1,6-enyne 6 [64] was also reacted with 3-bromoiodobenzene under the same reaction conditions and led to the formation of substrate $\mathbf{2 f}$ in $58 \%$ isolated yield. We also envisaged preparing two trisubstituted alkenes $\mathbf{2 g}$ and $\mathbf{2 h}$ by an alkylation/ Sonogashira sequence starting from commercially available substrates $\mathbf{7}$ and $\mathbf{8}$.

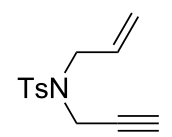

$1 \mathrm{~b}$

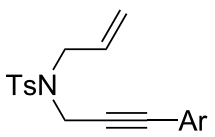

$\mathrm{Ar}=4-\mathrm{MeOC}_{6} \mathrm{H}_{4}$ 1c $\mathrm{Ar}=4-\mathrm{NO}_{2} \mathrm{C}_{6} \mathrm{H}_{4} 1 \mathrm{~d}$

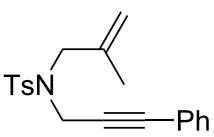

$1 \mathrm{e}$
Scheme 3: Nitrogen-tethered 1,6-enynes.
We also selected some nitrogen-tethered 1,6-enynes $\mathbf{1 b}-\mathbf{e}$ from the literature $[23,41-44]$ and synthesized them to evaluate the efficiency of the gold chiral catalytic system (Scheme 3).

\section{Scope and limitations of the catalytic system}

The prepared heteroatom-linked 1,6-enynes were then engaged in the cycloisomerization process in the presence of $\mathrm{Au}(\mathrm{I})$ cationic catalyst generated by mixing $(R)-4-\mathrm{MeO}-3,5-(t-\mathrm{Bu})_{2}-$ MeOBIPHEP- $(\mathrm{AuCl})_{2}$ complex and silver salts (Table 2). Anticipating the moderate reactivity of nitrogen-tethered enynes 1 , the reactions were conducted at $60^{\circ} \mathrm{C}$ in toluene (Table 2 , entries 1-5). The substitution of the aromatic ring on the alkyne moiety led to a substantial decrease of both isolated yields and ee's, as the presence of several by-products was detected, presumably due to degradation or polymerization [15]. A good ee was achieved in the case of enyne 1c, by using AgNTf $_{2}$ [65] instead of AgOTf (Table 2, entry 2 compared to entry 1). The substitution of the allylic side chain seemed to slow down the degradation process, as the cyclic alkene $3 \mathrm{e}$ was isolated in $61 \%$ yield (Table 2, entry 4 ). In the case of non-substituted enyne $\mathbf{1 b}$ (Table 2, entry 5), the bicyclic alkenyl derivative $\mathbf{3 b}$ was isolated in low yield and ee: The synthesis of $\mathbf{3 b}$ was accompanied by the formation of known 1,3- and 1,4-dienes (5\% and $10 \%$ isolated yield respectively) resulting from 5 -exo- and 6 -endo cycloisomerization reactions [20,66]. Thus, the gold catalytic system cannot compete with the results obtained for the cyclizations of nitrogen-tethered enynes in the presence of iridium, platinum or rhodium catalysts [41-45]. The cycloiso- 
Table 2: Cycloisomerization reaction of nitrogen- and oxygen-linked 1,6-enynes.

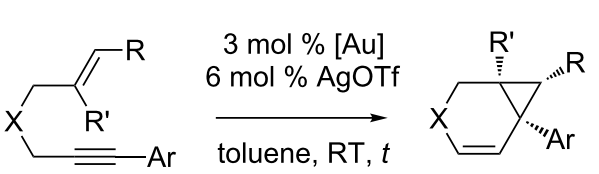

$1 b-e, 2 b-f$

$[\mathrm{Au}]=(R)-4-\mathrm{MeO}-3,5-(t-\mathrm{Bu})_{2} \mathrm{MeOBIPHEP}-(\mathrm{AuCl})_{2}$
$X=N T s \quad A r=R=R^{\prime}=H 1 b$

$\mathrm{Ar}=4-\mathrm{MeOC}_{6} \mathrm{H}_{4}, \mathrm{R}=\mathrm{R}^{\prime}=\mathrm{H} 1 \mathrm{c}$

$\mathrm{Ar}=4-\mathrm{NO}_{2} \mathrm{C}_{6} \mathrm{H}_{4}, \mathrm{R}=\mathrm{R}^{\prime}=\mathrm{H} \mathbf{1 d}$

$\mathrm{Ar}=\mathrm{Ph}, \mathrm{R}=\mathrm{H}, \mathrm{R}^{\prime}=\mathrm{Me} 1 \mathrm{e}$

$X=\mathrm{O} \quad \mathrm{Ar}=3,5-\mathrm{Me}_{2} \mathrm{C}_{6} \mathrm{H}_{3}, \mathrm{R}=\mathrm{Ph}, \mathrm{R}^{\prime}=\mathrm{H} \mathbf{2 b}$

$\mathrm{Ar}=4-\mathrm{CO}_{2} \mathrm{MeC}_{6} \mathrm{H}_{4}, \mathrm{R}=\mathrm{Ph}, \mathrm{R}^{\prime}=\mathrm{H}$ 2c

$\mathrm{Ar}=4-\mathrm{NO}_{2} \mathrm{C}_{6} \mathrm{H}_{4}, \mathrm{R}=\mathrm{Ph}, \mathrm{R}^{\prime}=\mathrm{H} \mathbf{2 d}$

$\mathrm{Ar}=3-\mathrm{BrC}_{6} \mathrm{H}_{4}, \mathrm{R}=\mathrm{Ph}, \mathrm{R}^{\prime}=\mathrm{H} \mathbf{2 e}$

$\mathrm{Ar}=3-\mathrm{BrC}_{6} \mathrm{H}_{4}, \mathrm{R}=4-\mathrm{MeOC}_{6} \mathrm{H}_{4}, \mathrm{R}^{\prime}=\mathrm{H} \mathbf{2 f}$

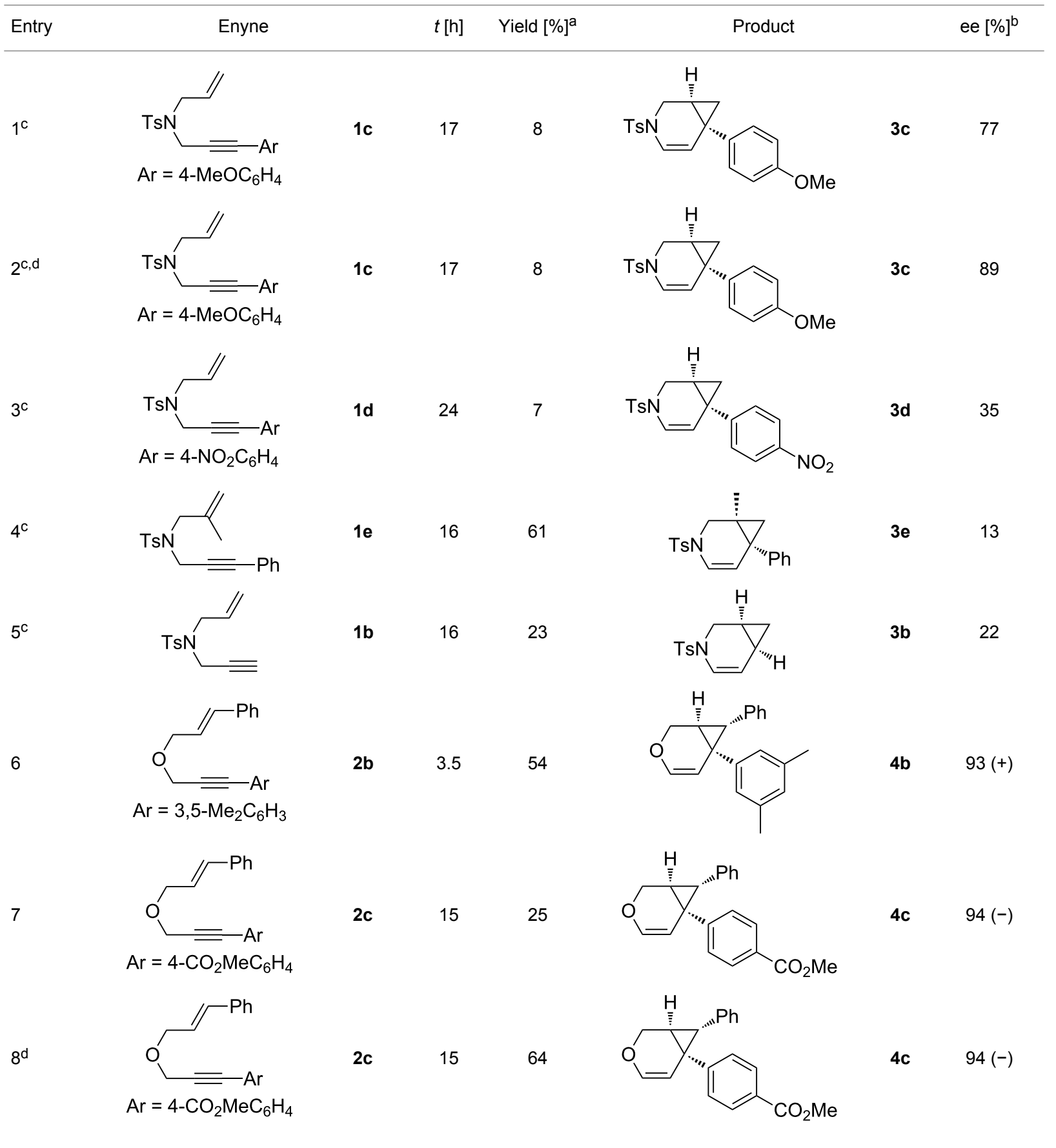


Table 2: Cycloisomerization reaction of nitrogen- and oxygen-linked 1,6-enynes. (continued)

9

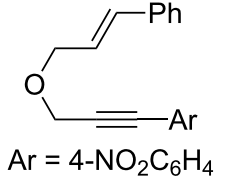

$10^{\mathrm{d}}$

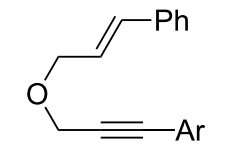

$\mathrm{Ar}=4-\mathrm{NO}_{2} \mathrm{C}_{6} \mathrm{H}_{4}$

11

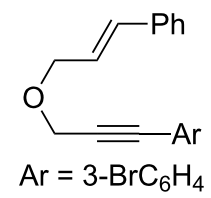

12

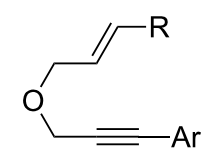

$\mathrm{R}=4-\mathrm{MeOC}_{6} \mathrm{H}_{4}$

$\mathrm{Ar}=3-\mathrm{BrC}_{6} \mathrm{H}_{4}$
$2 d$

15

32<smiles>O=[N+]([O-])c1ccc([C@]23C=COC[C@H]2[C@H]3c2ccccc2)cc1</smiles>

15

59<smiles>Brc1cccc([C@]23C=COC[C@H]2[C@H]3c2ccccc2)c1</smiles>

37

63

$2 \mathrm{e}$

30

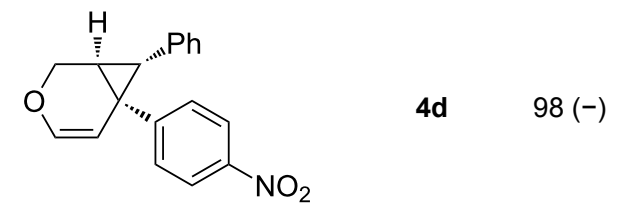

4d

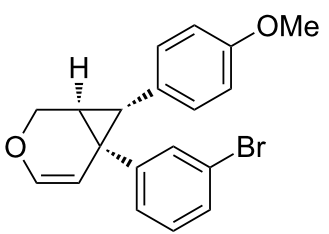

4 e $\quad 95(-)$

$4 \mathbf{4} \quad 95(-)$

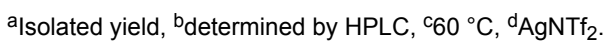

merization process was found to be highly stereoselective in the case of oxygen-tethered enynes (Table 2, entries 6-12). In all cases, the ee's were greater than $90 \%$ and in one case as high as $98 \%$. The stability of the resulting bicyclic alkenes $\mathbf{4}$ was generally only moderate, which led to low isolated yields. In the case of 1,6-enynes $2 \mathrm{c}$ and $\mathbf{2 d}$, the low yields (25\% and $32 \%$ respectively) could be improved by switching from AgOTf salt to $\mathrm{AgNTf}_{2}$, presumably due to the experimentally observed lower hygroscopicity of bistriflimide complex (Table 2, entry 7 compared to 8 and 9 compared to 10 ). The functionalized derivatives $4 \mathbf{c}$ and $\mathbf{4 d}$ were obtained in $64 \%$ and $63 \%$ yields respectively and in excellent ee's (Table 2 , entries 8 and 10). The compatibility with another functional group on the aromatic ring such as bromine (Table 2, entry 11), and with a different allylic side chain (Table 2, entry 12) was also evaluated: The corresponding bicyclic adducts $4 \mathbf{e}$ and $\mathbf{4 f}$ were isolated in modest to good yield and $95 \%$ ee.

Considering the observed highly stereoselective reactions of oxygen-tethered 1,6-enynes, we decided to study the challenging asymmetric synthesis of pentasubstituted cyclopropyl derivatives [67-70] (Scheme 4). The bicyclic derivative $4 \mathbf{h}$ was obtained in moderate yield and $73 \%$ ee. Conducting the reaction at $0{ }^{\circ} \mathrm{C}$ and using $\mathrm{AgNTf}_{2}$ as a chloride scavenger led to the formation of the alkenyl functionalized derivative $4 \mathrm{~g}$ in $36 \%$ isolated yield and excellent $99 \%$ ee.

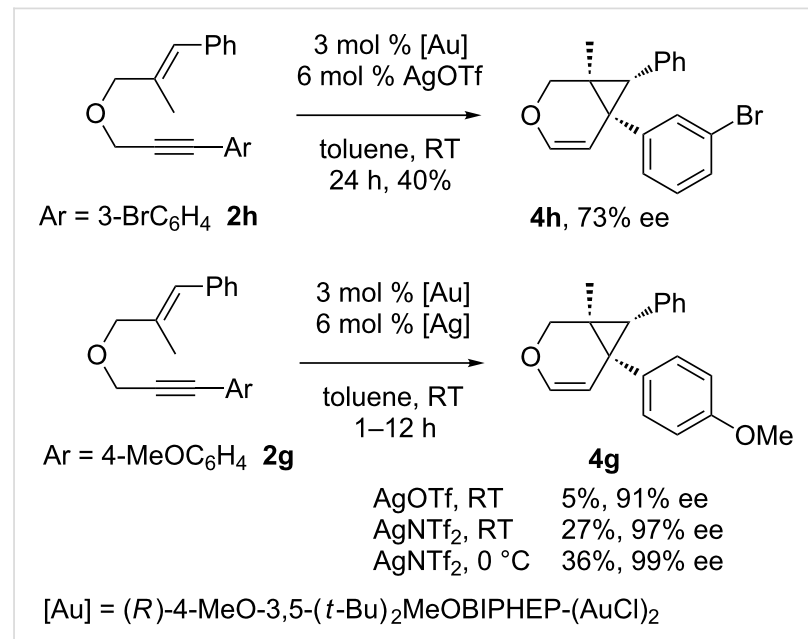

Scheme 4: Synthesis of pentasubstituted bicyclic cyclopropanes.

\section{Conclusion}

In conclusion, we have contributed to the development of an asymmetric gold-catalyzed cycloisomerization reaction allowing the formation of oxa- and aza-bicyclo[4.1.0]heptene derivatives. The combination of chiral $\mathrm{Au}(\mathrm{I})$ complex $(R)-4-$ $\mathrm{MeO}-3,5-(t-\mathrm{Bu})_{2}$-MeOBIPHEP- $(\mathrm{AuCl})_{2}$ associated to silver salts promotes the enantioselective rearrangement of oxygen and nitrogen-tethered 1,6-enynes in toluene at room temperature or $60{ }^{\circ} \mathrm{C}$. The cycloisomerization reactions were found to 
be highly substrate-dependent as low yield and ee's were generally obtained in the case of nitrogen-tethered enynes. The enantiomerically enriched functionalized oxabicyclo[4.1.0]heptenes were isolated in moderate yields but with excellent ee values ranging from $73 \%$ to $99 \%$. This methodology was successfully applied to the synthesis of pentasubstituted cyclopropyl heterobicycles.

\section{Experimental}

All reactions were carried out under an argon atmosphere. ${ }^{1} \mathrm{H}$ NMR and ${ }^{13} \mathrm{C}$ NMR were recorded on a Bruker AV 300 instrument. All signals were expressed as ppm $(\delta)$ and internally referenced to residual proton solvent signals. Coupling constants $(J)$ are reported in $\mathrm{Hz}$ and refer to apparent peak multiplicities. Enantiomeric excesses were determined by high pressure liquid chromatography analyses (HPLC) on Waters instruments (Waters 486 detector, 717 autosampler equipped with Daicel Chiralcel OD-H, OJ and Chiralpak IA, AD, $\lambda=215$ $\mathrm{nm})$. Optical rotation measurements were conducted on a Perkin-Elmer 241 polarimeter at $589 \mathrm{~nm}$. Enynes 5 [71], 2a [72], 2b-e [46], 1a [73], 1b [74], 1c,d [75], 1e [73], and 6 [64] were prepared according to published procedures. ${ }^{1} \mathrm{H}$, ${ }^{13} \mathrm{C}$ NMR and mass spectrometry data for compounds $\mathbf{3 a}, \mathbf{b}$ [23], 3c,d [75], 3e [76] and 4a-e [46] were described elsewhere.

(E)-1-Bromo-3-(3-(3-(4-methoxyphenyl)allyloxy)prop-1ynyl)benzene (2f): $\mathrm{CuI}$ (46 mg, 0.1 equiv) and $\mathrm{PdCl}_{2}\left(\mathrm{PPh}_{3}\right)_{2}$ ( $86 \mathrm{mg}, 0.05$ equiv) were placed in a Schlenk tube under argon. Distilled diisopropylamine $(3 \mathrm{~mL})$ was added and the reaction mixture was stirred at RT for 5 min. 1-Bromo-3-iodobenzene $(0.4 \mathrm{~mL}, 1.3$ equiv) was added and the reaction mixture was stirred for $5 \mathrm{~min}$. Enyne 6, dissolved in $2 \mathrm{~mL}$ of distilled diisopropylamine was added and the reaction mixture stirred for $3 \mathrm{~h}$ at RT. After hydrolysis with sat. aq. $\mathrm{NH}_{4} \mathrm{Cl}$ solution, the aqueous phase was extracted with EtOAc. The organic layer was successively washed with sat. aq. $\mathrm{NH}_{4} \mathrm{Cl}$ solution and brine. The organic layer was then dried with $\mathrm{MgSO}_{4}$, filtered and the solvents were evaporated under reduced pressure. The crude product was purified by silica gel chromatography (cyclohexane/ethyl acetate 90:10) to give $\mathbf{2 f}$ as a colorless oil (509 $\mathrm{mg}, 58 \%$ ). TLC (cyclohexane/ethyl acetate 70:30) $R_{\mathrm{f}} 0.77$; ${ }^{1} \mathrm{H}$ NMR $\left(300 \mathrm{MHz}, \mathrm{CDCl}_{3}\right) \delta 3.71(\mathrm{~s}, 3 \mathrm{H}), 4.17(\mathrm{dd}, J=6.3$, $1.2 \mathrm{~Hz}, 2 \mathrm{H}), 4.30$ (s, 2H), 6.08 (dt, $J=15.9,6.3 \mathrm{~Hz}, 1 \mathrm{H}), 6.52$ $(\mathrm{d}, J=15.9 \mathrm{~Hz}, 1 \mathrm{H}), 6.76(\mathrm{~d}, J=8.8 \mathrm{~Hz}, 2 \mathrm{H}), 7.07(\mathrm{t}, J=7.9$ $\mathrm{Hz}, 1 \mathrm{H}), 7.16-7.33(\mathrm{~m}, 3 \mathrm{H}), 7.36(\mathrm{dt}, J=8.0,1.1 \mathrm{~Hz}, 1 \mathrm{H}), 7.5$ $(\mathrm{t}, J=1.6 \mathrm{~Hz}, 1 \mathrm{H}) ;{ }^{13} \mathrm{C} \mathrm{NMR}\left(75 \mathrm{MHz}, \mathrm{CDCl}_{3}\right) \delta 55.6,57.9$, $71.0,85.1,87.1,114.4(2 \mathrm{C}), 122.4,123.2,125.1,128.1(2 \mathrm{C})$, $129.7,130.1,130.7,132.0,133.6,134.9,159.8$.

(E)-1-Methoxy-4-(3-(2-methyl-3-phenylallyloxy)prop-1ynyl)benzene (2g): Following the same procedure as for the synthesis of $\mathbf{2 f}$, in the presence of $\mathrm{CuI}$ (103 $\mathrm{mg}, 0.1$ equiv) and $\mathrm{PdCl}_{2}\left(\mathrm{PPh}_{3}\right)_{2}$ (190 mg, 0.05 equiv), 1-methoxy-4-iodobenzene (1.52 g, 1.2 equiv) in distilled diisopropylamine $(10 \mathrm{~mL}),(E)$ (2-methyl-3-(prop-2-ynyloxy)prop-1-enyl)benzene [77] (1 g, 1 equiv) was transformed to $\mathbf{2 g}(896 \mathrm{mg})$ in $57 \%$ yield. TLC (cyclohexane/ethyl acetate 90:10) $R_{\mathrm{f}} 0.71 ;{ }^{1} \mathrm{H}$ NMR $(300 \mathrm{MHz}$, $\left.\mathrm{CDCl}_{3}\right) \delta 2.20(\mathrm{~d}, J=1.2 \mathrm{~Hz}, 3 \mathrm{H}), 4.07(\mathrm{~s}, 3 \mathrm{H}), 4.44(\mathrm{~d}, J=0.9$ $\mathrm{Hz}, 2 \mathrm{H}), 4.66(\mathrm{~s}, 2 \mathrm{H}), 6.83(\mathrm{~s}, 1 \mathrm{H}), 7.11(\mathrm{~m}, 2 \mathrm{H}), 7.68-7.48(\mathrm{~m}$, $7 \mathrm{H}) ;{ }^{13} \mathrm{C} \mathrm{NMR}\left(75 \mathrm{MHz}, \mathrm{CDCl}_{3}\right) \delta 15.7,55.3,57.8,76.0,83.8$, $86.2,113.9,114.8,126.5,127.8,128.1$ (2C), 128.9 (2C), 133.3 (2C), $134.5,137.4,159.7$.

(E)-1-Bromo-3-(3-(2-methyl-3-phenylallyloxy)prop-1ynyl)benzene (2h): Following the same procedure as for the synthesis of $\mathbf{2 f}$, in the presence of $\mathrm{CuI}(62 \mathrm{mg}, 0.1$ equiv) and $\mathrm{PdCl}_{2}\left(\mathrm{PPh}_{3}\right)_{2}$ (115 mg, 0.05 equiv), 1-bromo-3-iodobenzene $(0.53 \mathrm{~mL}, 1.3$ equiv) in distilled diisopropylamine $(6.8 \mathrm{~mL})$, (E)-(2-methyl-3-(prop-2-ynyloxy)prop-1-enyl)benzene [77] (611 $\mathrm{mg}, 1$ equiv) was transformed to $\mathbf{2 h}(851 \mathrm{mg})$ in $76 \%$ yield. TLC (cyclohexane/ethyl acetate 90:10) $R_{\mathrm{f}} 0.63 ;{ }^{1} \mathrm{H}$ NMR $\left(300 \mathrm{MHz}, \mathrm{CDCl}_{3}\right) \delta 2.08(\mathrm{~d}, J=1.3 \mathrm{~Hz}, 3 \mathrm{H}), 4.31(\mathrm{~d}, J=0.8$ $\mathrm{Hz}, 2 \mathrm{H}), 4.53$ (s, 2H), $6.71(\mathrm{~d}, J=1.0 \mathrm{~Hz}, 1 \mathrm{H}), 7.30$ (t, $J=7.8$ $\mathrm{Hz}, 1 \mathrm{H}), 7.36-7.56(\mathrm{~m}, 6 \mathrm{H}), 7.58(\mathrm{dt}, J=8.0,0.8 \mathrm{~Hz}, 1 \mathrm{H}), 7.75$ $(\mathrm{t}, J=1.6 \mathrm{~Hz}, 1 \mathrm{H}) ;{ }^{13} \mathrm{C} \mathrm{NMR}\left(75 \mathrm{MHz}, \mathrm{CDCl}_{3}\right) \delta 16.0,58.0$ (2C), 85.1, 87.1, 122.5, 125.1, 127.0, 128.3, 128.5 (2C), 129.3 (2C), 130.1, 130.7, 132.0, 134.7, 134.9, 137.7.

General procedure for $\mathrm{Au}(\mathrm{I})$-catalyzed cycloisomerization reactions: A mixture of $\mathrm{L}-(\mathrm{AuCl})_{2}(\mathrm{~L}=(R)-4-\mathrm{MeO}-3,5-$ $\left.(t \text {-Bu })_{2} \mathrm{MeOBIPHEP}\right)(3 \mathrm{~mol} \%)$ and AgOTf (or $\left.\mathrm{AgNTf}_{2}\right)(6$ mol \%) in distilled toluene $(0.5 \mathrm{M})$ was stirred under an argon atmosphere at room temperature for $30 \mathrm{~min}$. Enyne (1 equiv) was then added and the mixture stirred until completion of the reaction. The mixture was then filtered through a short pad of silica to eliminate the catalyst (EtOAc) and the solvents were concentrated under reduced pressure. The crude product was purified by silica gel flash chromatography (petroleum ether/ ethyl acetate $98: 2$ to $80: 20 \mathrm{v} / \mathrm{v}$ ) if necessary.

6-(3-Bromophenyl)-7-(4-methoxyphenyl)-3-oxabicyclo[4.1.0]hept-4-ene (4f): TLC (cyclohexane/ethyl acetate 80:20) $R_{\mathrm{f}} 0.70 ;{ }^{1} \mathrm{H}$ NMR $\left(300 \mathrm{MHz}, \mathrm{CDCl}_{3}\right) \delta 2.29$ (d, $J=5.4$ $\mathrm{Hz}, 1 \mathrm{H}), 2.65(\mathrm{~d}, J=6.0 \mathrm{~Hz}, 1 \mathrm{H}), 3.61(\mathrm{~s}, 3 \mathrm{H}), 3.96(\mathrm{dd}, J=$ $10.6,1.9 \mathrm{~Hz}, 1 \mathrm{H}), 4.30$ (d, $J=10.6 \mathrm{~Hz}, 1 \mathrm{H}), 5.21$ (d, $J=6.0$ $\mathrm{Hz}, 1 \mathrm{H}), 6.18(\mathrm{~d}, J=6.0 \mathrm{~Hz}, 1 \mathrm{H}), 6.52-6.65(\mathrm{~m}, 4 \mathrm{H}), 6.86-6.92$ $(\mathrm{m}, 2 \mathrm{H}), 7.12-7.19(\mathrm{~m}, 2 \mathrm{H}) ;{ }^{13} \mathrm{C} \mathrm{NMR}\left(75 \mathrm{MHz}, \mathrm{CDCl}_{3}\right) \delta$ 29.9, 30.3, 37.3, 55.5, 61.6, 111.0, 113.7 (2C), 122.5, 128.7, 129.0 (2C), 129.4, 129.9, 130.1, 133.0, 141.2, 142.8, 158.2; HPLC (Chiralpack AD, hexane/propan-2-ol (97:3), flow rate $1.0 \mathrm{~mL} / \mathrm{min}, \lambda=215 \mathrm{~nm}$ ): retention times 7 and $7.5 \mathrm{~min}$, ee $95 \% ;[\alpha]_{\mathrm{D}}^{23}-18.6\left(c 1, \mathrm{CHCl}_{3}\right)$. 
6-(4-Methoxyphenyl)-1-methyl-7-phenyl-3-oxabicyclo[4.1.0]hept-4-ene (4g): TLC (cyclohexane/ethyl acetate 90:10) $R_{\mathrm{f}} 0.66 ;{ }^{1} \mathrm{H}$ NMR (300 MHz, $\left.\mathrm{CDCl}_{3}\right) \delta 1.18(\mathrm{~s}, 3 \mathrm{H})$, $2.84(\mathrm{~s}, 1 \mathrm{H}), 3.73(\mathrm{~d}, J=10.4 \mathrm{~Hz}, 1 \mathrm{H}), 3.80(\mathrm{~s}, 3 \mathrm{H}), 4.15$ (d, $J=$ $10.4 \mathrm{~Hz}, 1 \mathrm{H}), 5.19(\mathrm{~d}, J=5.8,1 \mathrm{~Hz}, 1 \mathrm{H}), 6.21(\mathrm{~d}, J=5.8$ $\mathrm{Hz}, 1 \mathrm{H}), 6.80-6.86(\mathrm{~m}, 4 \mathrm{H}), 7.01-7.04(\mathrm{~m}, 2 \mathrm{H}), 7.12-7.15$ (m, $3 \mathrm{H}) ;{ }^{13} \mathrm{C} \mathrm{NMR}\left(75 \mathrm{MHz}, \mathrm{CDCl}_{3}\right) \delta 12.9,31.6,35.2,38.2,55.2$, $67.8,113.7,114.5,125.4,127.5$ (2C), 130.0 (2C), 130.7, 132.1 (2C), 137.5, 140.0, 158.1; HPLC (Chiralcel OJ, hexane/propan2-ol (99/1), flow rate $1.0 \mathrm{~mL} / \mathrm{min}, \lambda=215 \mathrm{~nm})$ : retention times 20.3 and $27.1 \mathrm{~min}$, ee $99 \%$; $[\alpha]_{\mathrm{D}}{ }^{23}+26.1\left(c 1, \mathrm{CHCl}_{3}\right)$.

6-(3-Bromophenyl)-1-methy l-7-phenyl-3-oxabicyclo[4.1.0]hept-4-ene (4h): TLC (cyclohexane/ethyl acetate 90:10) $R_{\mathrm{f}} 0.71 ;{ }^{1} \mathrm{H}$ NMR $\left(300 \mathrm{MHz}, \mathrm{CDCl}_{3}\right) \delta 1.10(\mathrm{~s}, 3 \mathrm{H})$, $2.80(\mathrm{~s}, 1 \mathrm{H}), 3.64(\mathrm{~d}, J=10.5 \mathrm{~Hz}, 1 \mathrm{H}), 4.07(\mathrm{~d}, J=10.5 \mathrm{~Hz}$, $1 \mathrm{H}), 5.09(\mathrm{~d}, J=5.8 \mathrm{~Hz}, 1 \mathrm{H}), 6.16(\mathrm{~d}, J=5.8 \mathrm{~Hz}, 1 \mathrm{H}), 6.75(\mathrm{~d}$, $J=2.1 \mathrm{~Hz}, 1 \mathrm{H}), 6.78(\mathrm{~d}, J=4.0 \mathrm{~Hz}, 1 \mathrm{H}), 6.92(\mathrm{dt}, J=7.7,1.4$ $\mathrm{Hz}, 1 \mathrm{H}), 7.00-7.20(\mathrm{~m}, 5 \mathrm{H}), 7.29$ (dt, $J=7.8,1.2 \mathrm{~Hz}, 1 \mathrm{H})$; ${ }^{13} \mathrm{C} \mathrm{NMR}\left(75 \mathrm{MHz}, \mathrm{CDCl}_{3}\right) \delta 14.4,33.2,36.5,39.7,68.9$, 114.6, 123.5, 127.2, 129.0 (2C), 131.1 (2C), 131.2, 131.3 (2C), 135.3, 138.2, 142.0, 142.5; HPLC (Chiralpak IA, hexane/ propan-2-ol (99.9:0.1), flow rate $0.5 \mathrm{~mL} / \mathrm{min}, \lambda=215 \mathrm{~nm})$ : retention times 11.8 and $12.6 \mathrm{~min}$, ee $73 \%$; $[\alpha]_{\mathrm{D}}{ }^{23}+11.7(c 1$, $\mathrm{CHCl}_{3}$ ).

\section{Supporting Information}

\section{Supporting Information File 1 \\ Spectral data. \\ [http://www.beilstein-journals.org/bjoc/content/ supplementary/1860-5397-7-116-S1.pdf]}

\section{Acknowledgements}

This work was supported by the Centre National de la Recherche Scientifique and the Ministère de l'Education et de la Recherche. Chung-Meng Chao is grateful to the Ministère de l'Education et de la Recherche for a grant (2006-2009). Alexandre Pradal is grateful to National Research Agency (ANR-09-JCJC-0078) for a grant (2009-2012). The authors thank Dr. M. Scalone (Hoffmann-La Roche) for the generous donation of 4-MeO-3,5-( $t$-Bu $)_{2}$-MeOBIPHEP ligand. JohnsonMatthey is acknowledged for a generous donation of $\mathrm{HAuCl}_{4}$.

\section{References}

1. Belmont, P.; Parker, E. Eur. J. Org. Chem. 2009, 6075. doi:10.1002/ejoc. 200900790

2. Jiménez-Núñez, E.; Echavarren, A. M. Chem. Rev. 2008, 108, 3326. doi:10.1021/cr0684319
3. Michelet, V.; Toullec, P. Y.; Genêt, J.-P. Angew. Chem., Int. Ed. 2008, 47, 4268. doi:10.1002/anie.200701589

4. Zhang, L.; Sun, J.; Kozmin, S. A. Adv. Synth. Catal. 2006, 348, 2271. doi:10.1002/adsc.200600368

5. Nevado, C.; Echavarren, A. M. Synthesis 2005, 167. doi:10.1055/s-2005-861781

6. Fairlamb, I. J. S. Angew. Chem., Int. Ed. 2004, 43, 1048. doi:10.1002/anie.200301699

7. Aubert, C.; Buisine, O.; Malacria, M. Chem. Rev. 2002, 102, 813. doi:10.1021/cr980054f

8. Trost, B. M.; Krische, M. J. Synlett 1998, 1. doi:10.1055/s-1998-1557

9. Soriano, E.; Marco-Contelles, J. Acc. Chem. Res. 2009, 42, 1026. doi:10.1021/ar800200m

10. Soriano, E.; Ballesteros, P.; Marco-Contelles, J. J. Org. Chem. 2004, 69, 8018. doi:10.1021/jo048828h

11. He, R.-X.; Li, M.; Li, X.-Y. THEOCHEM 2005, 717, 21. doi:10.1016/j.theochem.2004.10.067

12. Mandal, A. K.; Borude, D. P.; Armugasamy, R.; Soni, N. R.; Jawalker, D. G.; Mahajan, S. W.; Ratman, K. R.; Goghare, A. D. Tetrahedron 1986, 42, 5715. doi:10.1016/S0040-4020(01)88177-1 And references cited therein.

13. Tessier, J. R. In Recent Advances in the Chemistry of Insect Control; James, N. F., Ed.; Royal Soc. Chem.: London, 1985; p 26.

14. Blum, J.; Beer-Kraft, H.; Badrieh, Y. J. Org. Chem. 1995, 60, 5567. doi:10.1021/jo00122a043

15. Chatani, N.; Furukawa, N.; Sakurai, H.; Murai, S. Organometallics 1996, 15, 901. doi:10.1021/om950832j

16. Lloyd-Jones, G. C. Org. Biomol. Chem. 2003, 1, 215. doi:10.1039/b209175p

17. Bruneau, C. Angew. Chem., Int. Ed. 2005, 44, 2328. doi:10.1002/anie.200462568

18. Chianese, A. R.; Lee, S. J.; Gagné, M. R. Angew. Chem., Int. Ed. 2007, 46, 4042. doi:10.1002/anie.200603954

19. Fürstner, A.; Davies, P. W. Angew. Chem., Int. Ed. 2007, 46, 3410. doi:10.1002/anie.200604335

20. Lee, S. I.; Chatani, N. Chem. Commun. 2009, 371. doi:10.1039/b812466c

21. Fürstner, A. Chem. Soc. Rev. 2009, 38, 3208. doi:10.1039/b816696j

22. Toullec, P. Y.; Michelet, V. Top. Curr. Chem. 2011, 1. doi:10.1007/128_2010_116

23. Fürstner, A.; Szillat, H.; Stelzer, F. J. Am. Chem. Soc. 2000, 122, 6785 doi:10.1021/ja001034+

24. Fürstner, A.; Stelzer, F.; Szillat, H. J. Am. Chem. Soc. 2001, 123, 11863. doi:10.1021/ja0109343

25. Méndez, M.; Muñoz, M. P.; Nevado, C.; Cárdenas, D. J.; Echavarren, A. M. J. Am. Chem. Soc. 2001, 123, 10511. doi:10.1021/ja0112184

26. Nevado, C.; Ferrer, C.; Echavarren, A. M. Org. Lett. 2004, 6, 3191. doi:10.1021/ol0486573

27. Lee, S. I.; Kim, S. M.; Choi, M. R.; Kim, S. Y.; Chung, Y. K. J. Org. Chem. 2006, 71, 9366. doi:10.1021/jo061254r

28. Ferrer, C.; Raducan, M.; Nevado, C.; Claverie, C. K.; Echavarren, A. M. Tetrahedron 2007, 63, 6306. doi:10.1016/j.tet.2007.02.122

29. Ye, L.; Chen, Q.; Zhang, J.; Michelet, V. J. Org. Chem. 2009, 74, 9550. doi:10.1021/jo902083r

30. Harrak, Y.; Simonneau, A.; Malacria, M.; Gandon, V.; Fensterbank, L. Chem. Commun. 2010, 46, 865. doi:10.1039/b919240a

31. Mamane, V.; Gress, T.; Krause, H.; Fürstner, A. J. Am. Chem. Soc. 2004, 126, 8654. doi:10.1021/ja048094q 
32. Harrak, Y.; Blaszylowski, C.; Bernard, M.; Cariou, K.; Mainetti, E.; Mouriès, V.; Dhimane, A.-L.; Fensterbank, L.; Malacria, M. J. Am. Chem. Soc. 2004, 126, 8656. doi:10.1021/ja0474695

33. Blaszykowski, C.; Harrak, Y.; Gonçalves, M.-H.; Cloarec, J.-M.; Dhimane, A.-L.; Fensterbank, L.; Malacria, M. Org. Lett. 2004, 6, 3771. doi:10.1021/ol048463n

34. Luzung, M. R.; Markham, J. P.; Toste, F. D. J. Am. Chem. Soc. 2004, 126, 10858. doi:10.1021/ja046248w

35. Gagosz, F. Org. Lett. 2005, 7, 4129. doi:10.1021/ol051397k

36. Sun, J.; Conley, M. P.; Zhang, L.; Kozmin, S. A. J. Am. Chem. Soc. 2006, 128, 9705. doi:10.1021/ja063384n

37. Couty, S.; Meyer, C.; Cossy, J. Angew. Chem., Int. Ed. 2006, 45, 6726. doi:10.1002/anie.200602270

38. Blaszylowski, C.; Harrak, Y.; Brancour, C.; Nakama, K.; Dhimane, A.-L.; Fensterbank, L.; Malacria, M. Synthesis 2007, 13, 2037. doi:10.1055/s-2007-983736

39. Couty, S.; Meyer, C.; Cossy, J. Tetrahedron 2009, 65, 1809. doi:10.1016/j.tet.2008.10.108

40. Horino, Y.; Yamamoto, T.; Ueda, K.; Kuroda, S.; Toste, F. D. J. Am. Chem. Soc. 2009, 131, 2809. doi:10.1021/ja808780r

41. Shibata, T.; Kobayashi, Y.; Maekawa, S.; Toshida, N.; Takagi, K. Tetrahedron 2005, 61, 9018. doi:10.1016/j.tet.2005.07.039

42. Brissy, D.; Skander, M.; Jullien, H.; Retailleau, P.; Marinetti, A. Org. Lett. 2009, 11, 2137. doi:10.1021/ol900724z

43. Brissy, D.; Skander, M.; Retailleau, P.; Marinetti, A. Organometallics 2007, 26, 5782. doi:10.1021/om700839y

44. Brissy, D.; Skander, M.; Retailleau, P.; Frison, G.; Marinetti, A. Organometallics 2009, 28, 140. doi:10.1021/om800743r

45. Nishimura, T.; Kawamoto, T.; Nagaosa, M.; Kumamoto, H.; Hayashi, T. Angew. Chem., Int. Ed. 2010, 49, 1638. doi:10.1002/anie.200906792

46. Chao, C.-M.; Beltrami, D.; Toullec, P. Y.; Michelet, V. Chem. Commun. 2009, 6988. doi:10.1039/b913554e

47. Deschamps, N. M.; Elitzin, V. I.; Liu, B.; Mitchell, M. B.; Sharp, M. J.; Tabet, E. A. J. Org. Chem. 2011, 76, 712. doi:10.1021/jo102098y

48. Teller, H.; Fürstner, A. Chem.-Eur. J. 2011, 17, 7764 doi:10.1002/chem.201101346

49. Chao, C.-M.; Vitale, M. R.; Toullec, P. Y.; Genêt, J.-P.; Michelet, V. Chem.-Eur. J. 2009, 15, 1319. doi:10.1002/chem.200802341

50. Chao, C.-M.; Genin, E.; Toullec, P. Y.; Genêt, J.-P.; Michelet, V. J. Organomet. Chem. 2009, 694, 538. doi:10.1016/j.jorganchem.2008.08.008

51. Andreiadis, E. S.; Vitale, M. R.; Mézailles, N.; Le Goff, X.; Le Floch, P.; Toullec, P. Y.; Michelet, V. Dalton Trans. 2010, 39, 10608. doi:10.1039/c0dt00399a

52. Pradal, A.; Chao, C.-M.; Vitale, M.; Toullec, P. Y.; Michelet, V. Tetrahedron 2011, 67, 4371. doi:10.1016/j.tet.2011.03.071

53. Widenhoefer, R. A. Chem.-Eur. J. 2008, 14, 5382. doi:10.1002/chem.200800219

54. Sengupta, S.; Shi, X. ChemCatChem 2010, 2, 609. doi:10.1002/cctc. 201000070

55. Pradal, A.; Toullec, P. Y.; Michelet, V. Synthesis 2011, 10, 1501. doi:10.1055/s-0030-1258465

56. Liu, C.; Widenhoefer, R. A. Org. Lett. 2007, 9, 1935. doi:10.1021/ol070483c

57. Muñoz, M. P.; Adrio, J.; Carretero, J. C.; Echavarren, A. M. Organometallics 2005, 24, 1293. doi:10.1021/om0491645
58. Schmid, R.; Broger, E. A.; Cereghetti, M.; Crameri, Y.; Foricher, J.; Lalonde, M.; Müller, R. K.; Scalone, M.; Schoettel, G.; Zutter, U. Pure Appl. Chem. 1996, 68, 131. doi:10.1351/pac199668010131 For the synthesis and applications in hydrogenation reactions of $(R)-4-\mathrm{MeO}-3,5-(t-\mathrm{Bu})_{2}-\mathrm{MeOBIPHEP}$ (and references cited therein).

59. The absolute configuration was proposed in analogy to the data concerning $\mathbf{4 a}$ and to literature [45].

60. Chinchilla, R.; Nájera, C. Chem. Rev. 2007, 107, 874. doi:10.1021/cr050992x

61. Doucet, H.; Hierso, J.-C. Angew. Chem., Int. Ed. 2007, 46, 834. doi:10.1002/anie.200602761

62. Nevado, C.; Charruault, L.; Michelet, V.; Nieto-Oberhuber, C.; Muñoz, M. P.; Méndez, M.; Rager, M.-N.; Genêt, J.-P.; Echavarren, A. M. Eur. J. Org. Chem. 2003, 706. doi:10.1002/ejoc.200390110

63. Galland, J.-C.; Savignac, M.; Genêt, J.-P. Tetrahedron Lett. 1997, 38, 8695. doi:10.1016/S0040-4039(97)10337-9

64. Michelet, V.; Charruault, L.; Gladiali, S.; Genêt, J.-P. Pure Appl. Chem. 2006, 78, 397. doi:10.1351/pac200678020397

65. Mézailles, N.; Ricard, L.; Gagosz, F. Org. Lett. 2005, 7, 4133. doi:10.1021/ol0515917

66. Nakai, H.; Chatani, N. Chem. Lett. 2007, 36, 1494. doi:10.1246/cl.2007.1494

67. Charette, A. B.; Beauchemin, A. Org. React. 2001, 58, 1.

68. Lebel, H.; Marcoux, J.-F.; Molinaro, C.; Charette, A. B. Chem. Rev. 2003, 103, 977. doi:10.1021/cr010007e

69. Pelissier, H. Tetrahedron 2008, 64, 7041. doi:10.1016/j.tet.2008.04.079

70. Doyle, M. P.; Forbes, D. C. Chem. Rev. 1998, 98, 911. doi:10.1021/cr940066a

71. Trost, B. M.; Edstrom, E. D.; Carter-Petillo, M. B. J. Org. Chem. 1989, 54, 4489. doi:10.1021/jo00280a006

72. Kudoh, T.; Mori, T.; Shirahama, M.; Yamada, M.; Ishikawa, T.; Saito, S.; Kobayashi, H. J. Am. Chem. Soc. 2007, 129, 4939. doi:10.1021/ja066485u

73. Morimoto, T.; Fuji, K.; Tsutsumi, K.; Kakiuchi, K. J. Am. Chem. Soc. 2002, 124, 3806. doi:10.1021/ja0126881

74. Oppolzer, W.; Pimm, A.; Stammen, B.; Hume, W. E. Helv. Chim. Acta 1997, 80, 623. doi:10.1002/hlca.19970800302

75. Tang, Y.; Deng, L.; Zhang, Y.; Dong, G.; Chen, J.; Yang, Z. Org. Lett. 2005, 7, 1657. doi:10.1021/ol050410y

76. Shibata, T.; Arai, Y.; Tahara, Y.-K. Org. Lett. 2005, 7, 4955. doi:10.1021/ol051876j

77. Mikami, K.; Hatano, M. Proc. Natl. Acad. Sci. U. S. A. 2004, 101, 5767. doi:10.1073/pnas.0307217101 


\section{License and Terms}

This is an Open Access article under the terms of the Creative Commons Attribution License

(http://creativecommons.org/licenses/by/2.0), which permits unrestricted use, distribution, and reproduction in any medium, provided the original work is properly cited.

The license is subject to the Beilstein Journal of Organic Chemistry terms and conditions:

(http://www.beilstein-journals.org/bjoc)

The definitive version of this article is the electronic one which can be found at:

doi:10.3762/bjoc.7.116 